Communication

\title{
Investigation of Landslides that Occurred in August on the Chengdu-Kunming Railway, Sichuan, China
}

\author{
Qian Zheng ${ }^{1,2}$, Shui-Long Shen ${ }^{1,2, * \mathbb{D}}$, An-Nan Zhou ${ }^{3}$ and Hao Cai ${ }^{2,4}$ \\ 1 Department of Civil and Environmental Engineering, College of Engineering, Shantou University, \\ Shantou 515063, China; 18hzheng3@stu.edu.cn \\ 2 Key Laboratory of Intelligent Manufacturing Technology (Shantou University), Ministry of Education, \\ Shantou University, Shantou 515063, China; haocai@stu.edu.cn \\ 3 Civil and Infrastructure Engineering Discipline, School of Engineering, Royal Melbourne Institute of \\ Technology (RMIT), Victoria 3001, Australia; annan.zhou@rmit.edu.au \\ 4 Department of Computer Engineering, College of Engineering, Shantou University, Shantou 515063, China \\ * Correspondence: shensl@stu.edu.cn; Tel.: +86-754-8650-4551
}

Received: 10 October 2019; Accepted: 23 November 2019; Published: 26 November 2019

\begin{abstract}
This paper reports on a large-scale landslide with a movement of 48 thousand $\mathrm{m}^{3}$ of soil and rock that occurred in Sichuan, China. This catastrophic landslide occurred in Aidai village, Ganluo County, at 12:44 on 14 August 2019, blocking a section of the railway between Lianghong station and Aidai station. This landslide resulted in 12 deaths and five people missing. This report describes the preliminary investigation, the rescue activity, topographic survey and analysis as well as the main predisposing and triggering factors. The combined effects of steep topography, continuous rainstorms, floods eroding the foothills of the mountain and human activity were the main influencing factors that triggered this landslide. To reduce the possibility of casualties resulting from large geological disasters, such as landslides and mudslides, in this region in the future, some recommendations are proposed to systematically reduce potential human casualties and economic losses.
\end{abstract}

Keywords: landslide; Ganluo; geology and landforms; rainstorm; recommendations

\section{Introduction}

Thousands of landslides happen every year worldwide causing deaths and large damages [1-3] among which China is one of the most seriously affected countries [1]. It is reported that 130 million people were affected by natural disasters in China in 2018 which killed 589 people, left 46 people missing, and caused direct economic loss of 264.46 billion yuan. According to statistics, 35.3 million people suffered floods and geological disasters nationwide which resulted in 338 deaths, 42 persons missing, and 1.42 million people urgently being relocated. In total, 64,000 houses collapsed, and, in addition, 139,000 were seriously damaged and 650,000 more were generally damaged. Direct economic losses reached 106.05 billion yuan (approximately $\$ 15.06$ billion USD) [4]. In addition, the total number of deaths from snow, drought, typhoon, and earthquake in 2018 was 103, and the total economic loss was 116.03 billion yuan (approximately \$16.5 billion USD) which together is equivalent to the losses by floods and geological disasters.

Landslides have been one of the main factors impeding state economic development, particularly in the western regions of China. Landslides have become a serious threat owing to the special landform and geological conditions prevailing in western China [5]. Even though rockslides and avalanches 
occur in remote mountainous areas [6], they still commonly cause traffic jams, block river flow systems, destroy factories and mines, bury villages and towns [7-9], and even result in significant human casualties. Landslides have drawn a tremendous amount of attention from many researchers, with efforts focused on finding methods to forecast their occurrence or to assess the related hazards [10-12]. Effective long-term participation of the emergency management department (EMD) and local residents continues to be an enormous challenge in disaster risk mitigation in landslide-prone areas.

Currently, early warning systems (EWSs) and post-disaster management systems are the most significant methods to reduce casualties and economic losses in high-occurrence disaster zones for landslides. The Norwegian water resources and energy directorate (NVE) [13], which is a part of the state responsibility management department, has been developing an integrated regional EWS for landslides. The objective of this system is to analyse, predict, and follow the hydrological and meteorological conditions available to trigger landslides. In addition, the system can warn the authorities of potential catastrophic events in advance. In South Korea, Dongyeob et al. [14] proposed a landslide EWS based on sensors in high landslide-prone sites in urban areas. The sensors are an integral part of the prevention and control system for sediment-related disasters. In Ethiopia, the Abay gorge [15] witnesses frequent landslides during the rainy season along Gohatsion-Dejen road. Therefore, the researchers divided the land surface there into regions of different disaster levels and conducted landslide hazard zonation (LHZ) mapping in the Abay gorge, combined with remote sensing (RS) and geographic information system (GIS) techniques.

Despite efforts made by researchers and governments worldwide, a series of continuous landslides occurred in the village of Aidai, Ganluo County, Sichuan Province, in 2019. The objective of this study was to conduct a preliminary investigation into this specific catastrophic landslide in Aidai including the actual occurrence of the landslide, rescue efforts and the analysis of causes and influential factors.

\section{Investigation}

A catastrophic landslide occurred in Aidai village, Ganluo County, at 12:44 on 14 August 2019, which blocked a section of the railway line between Lianghong and Aidai stations (see Figure 1). Ganluo County is located at the southwest of Chengdu, the capital of Sichuan, China. This section is a part of the railway between Chengdu and Kunming which is the only railway connecting China's southwest region to the other regions. In this landslide event, approximately $48,000 \mathrm{~m}^{3}$ of earth and rocks slid down the mountain from a height of about $190 \mathrm{~m}$ (the vertical distance between the highest point of the landslide and the railway). This landslide happened close to Aidai railway tunnel 2, and its duration was estimated to be approximately 6 s [16]. Figure 2a,b show photographs before and after the landslide, respectively.

Figure 3 presents an overall view of the site after landslide A (14 August 2019) occurred. The total length of the landslide was estimated to be approximately $316 \mathrm{~m}$. The width of the main scarp was $96 \mathrm{~m}$ at an altitude of $1182 \mathrm{~m}$. The width of the landslide toe was approximate $78 \mathrm{~m}$ at an altitude of $979 \mathrm{~m}$. The minimum width of the main body was estimated to be approximately $31 \mathrm{~m}$ at an altitude of $1047 \mathrm{~m}$. The main body buried a $70 \mathrm{~m}$ stretch of the railway line at an altitude of $964 \mathrm{~m}$. The area of main body was $20769 \mathrm{~m}^{2}$ (see Figure 4b). In addition, earth and rocks flowed into the Niri River and destroyed the surrounding houses, and the debris flowed into the adjacent tunnel outlet 2 . Landslide A resulted in 12 deaths and five people missing. Furthermore, this important railway track had to be closed until 30 August. Next to where landslide A occurred, a mudslide B occurred on 4 August 2019, which deposited approximately $4000 \mathrm{~m}^{3}$ of mud. Most of the dead and missing from landslide A were workers and railway staff working at the site to clear the culverts blocked by mudslide B. 


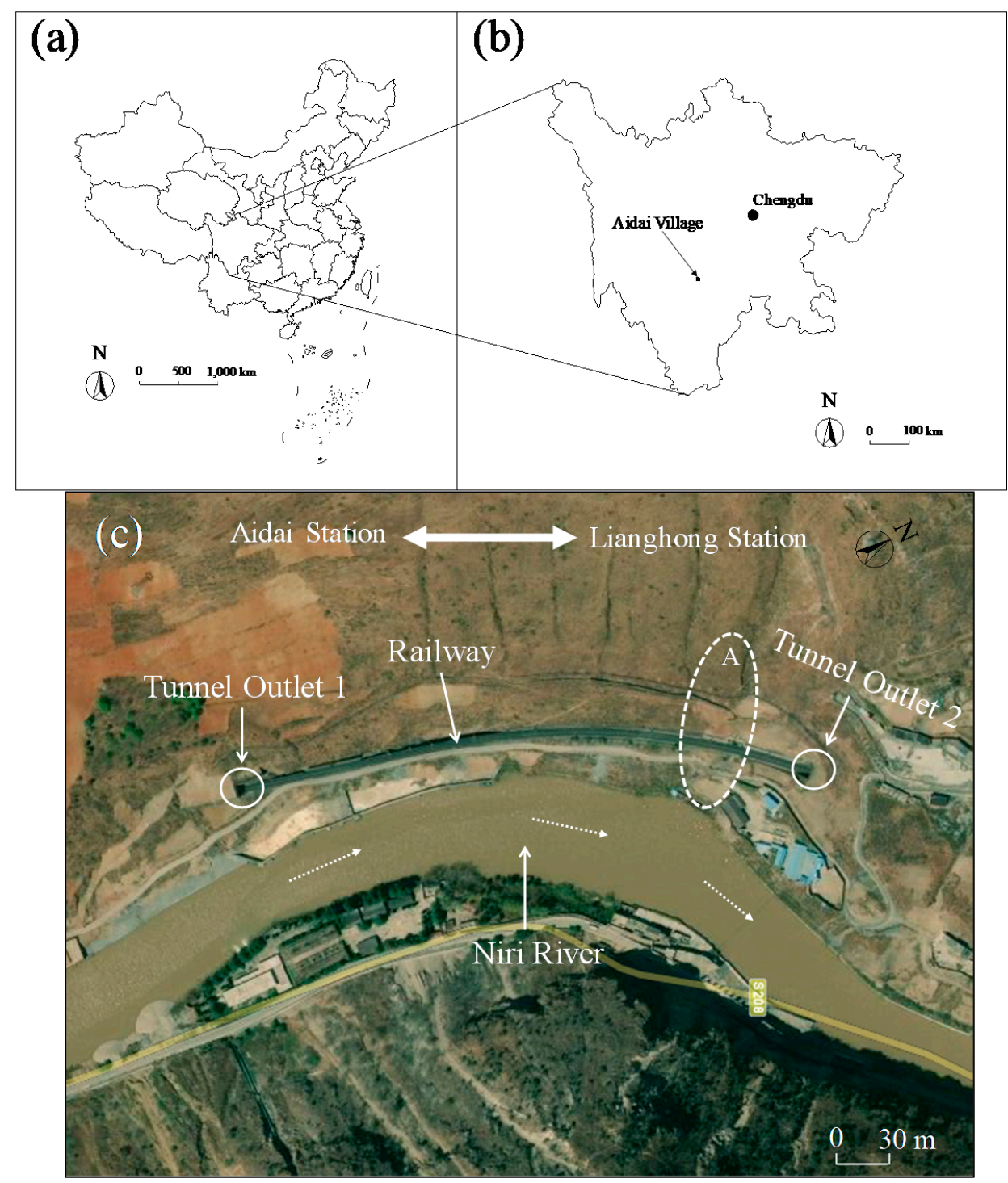

Figure 1. (a) Location of Sichuan; (b) location of Aidai village; (c) Satellite image depicting the location of the landslide and nearby topography (A depicts the landslide that occurred on 14 August 2019).
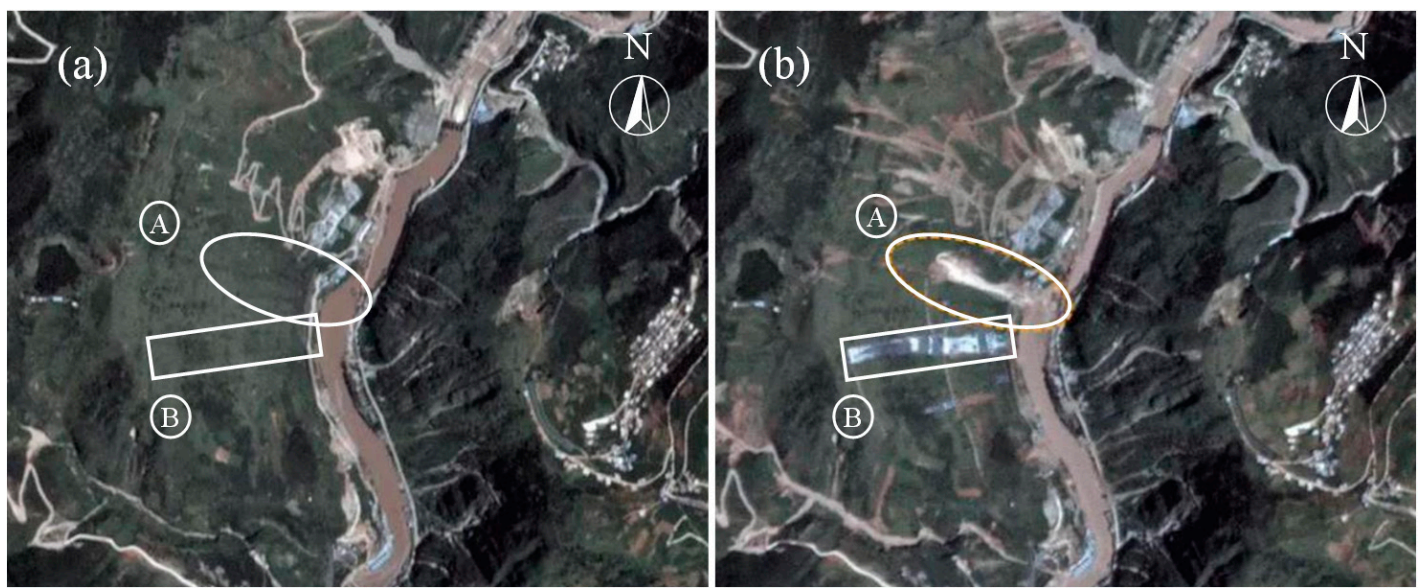

Figure 2. (a) Satellite imagery before the landslides. (b) Photo taken after the landslides. (A): The landslide on 14 August 2019. (B) The landslide on 4 August 2019, recreated based on Reference [17]. 


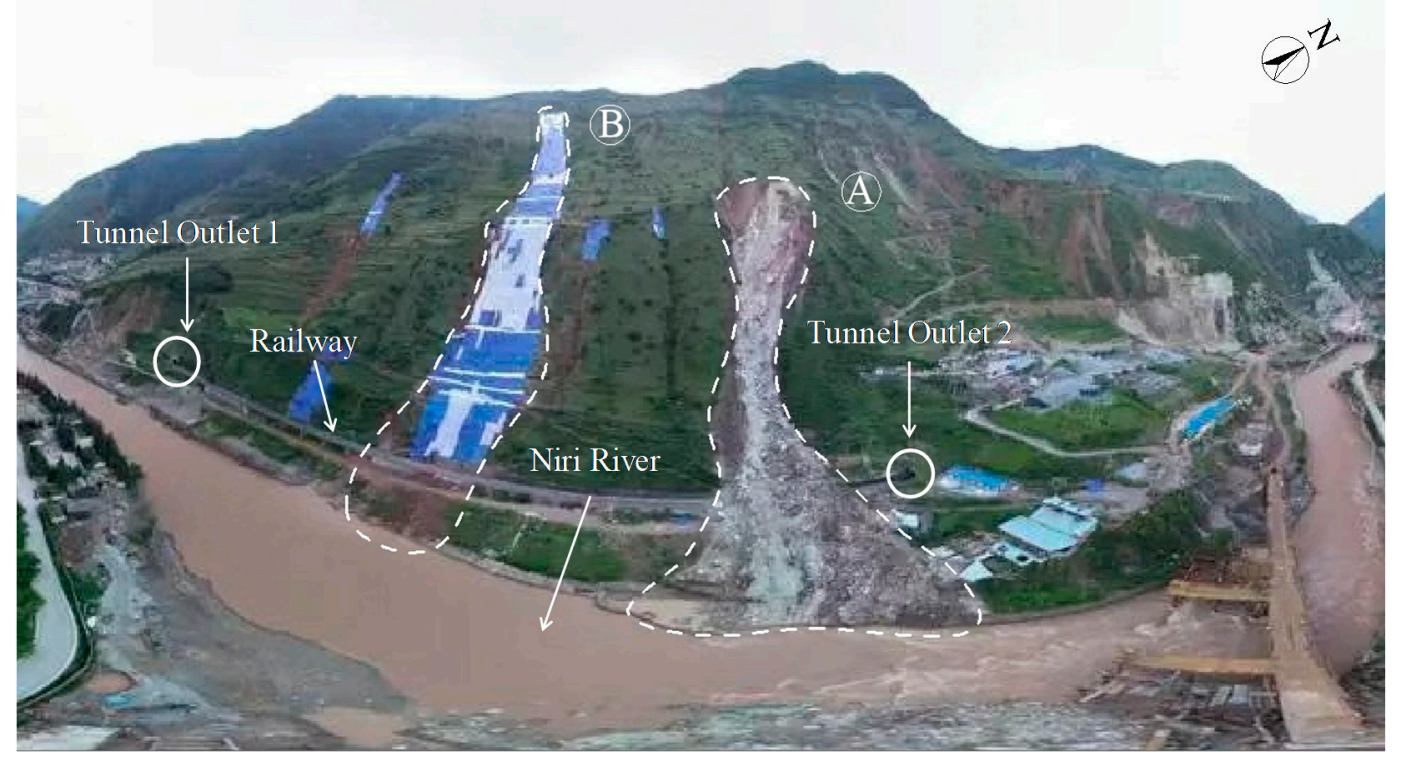

Figure 3. An overview of the landslide site. (A) The landslide on 14 August 2019. (B) The landslide on 4 August 2019, recreated based on Reference [18].
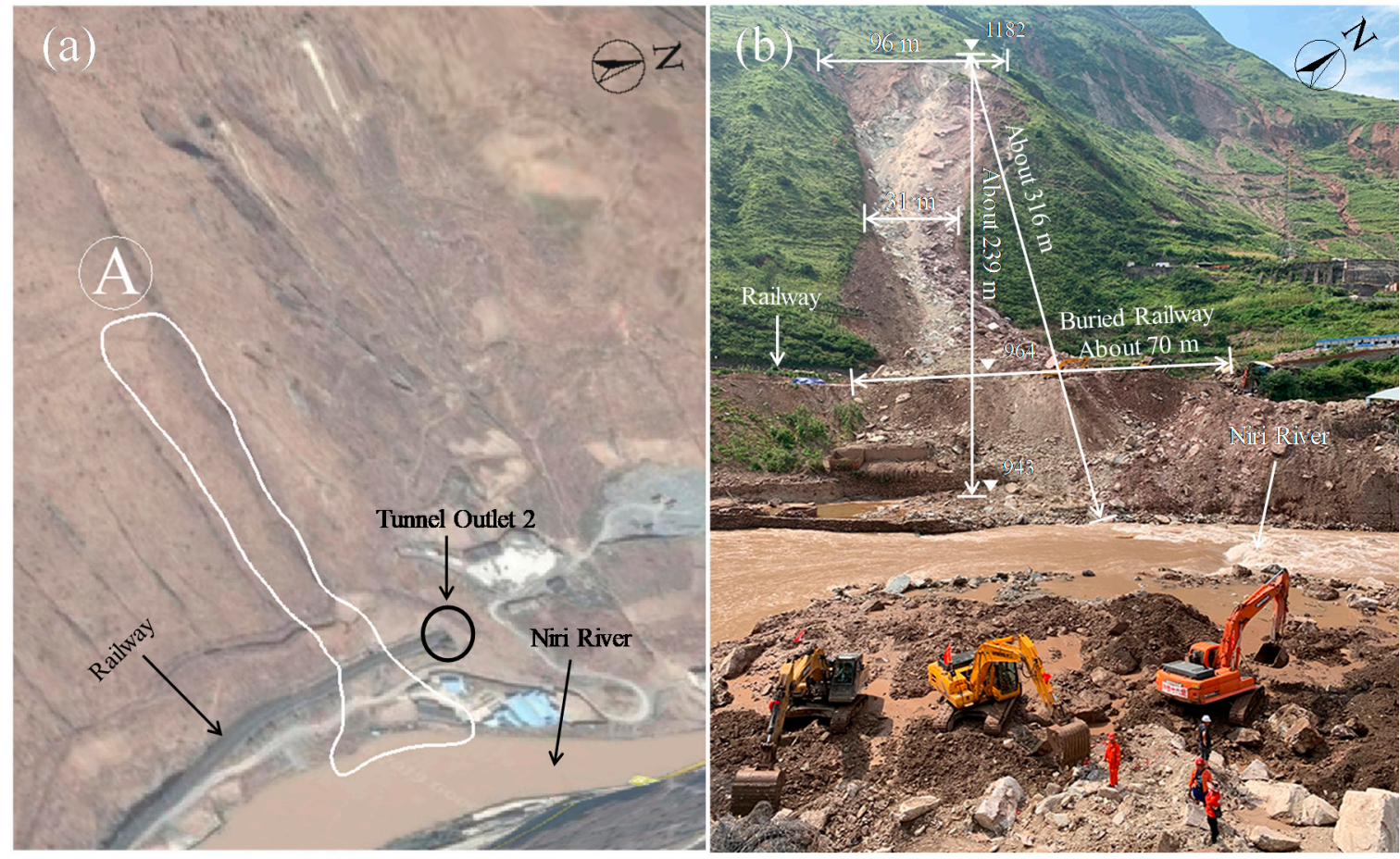

Figure 4. (a) 3D model taken from Google Earth before the landslide. (A) The landslide on 14 August. (b) A photo taken after the landslide (recreated based on Reference [19]). Data resources were from Reference [20].

\subsection{Data Source}

To analyse the event, the weather data records of Ganluo County were collected from the public records of Sina Weather (http://weather.sina.com.cn/ganluo) which included the annual average rainfall in Ganluo, the monthly average highest temperature, the monthly average lowest temperature and the daily rainfall recorded by the weather channel 20 days prior to the disaster. 


\subsection{Rescue Effort}

This large-scale landslide is believed to be the most serious landslide disaster ever to hit Ganluo County since 1981. The joint-force rescue operation involved more than 750 personnel including firefighters, armed police and militiamen who came from Ganluo County as well as other cities such as Chengdu and Panzhihua. Concurrently, to rescue the buried people, 39 pieces of mechanical rescue equipment were dispatched which included seven rail cars, eight sets of excavators to excavate the stocks, three sets of radar life detectors, audio and video detectors and lighting equipment. An additional 40 units of hydraulic fracturing equipment were also deployed. In addition, the emergency management department arranged three search and rescue dogs to help the rescuers search for missing persons and used drones for real-time monitoring of the changes happening on the surrounding mountains and the landslide face (see Figure 5).

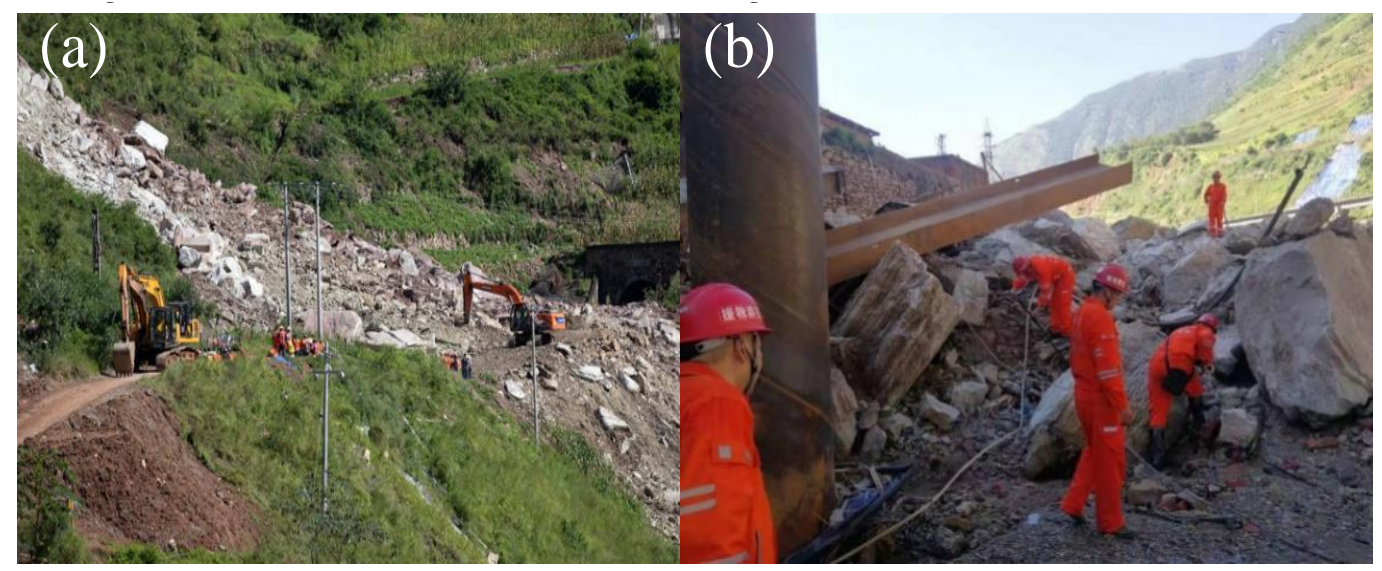

Figure 5. Rescue activities: (a) excavators clearing rubble (Picture source from [21]) and (b) workers clearing roads buried by soil (Picture source from [22]).

\section{Analysis and Discussion}

\subsection{Internal Factors: Geographical Position, Geological Conditions and Seismic Fracture Zone}

\subsubsection{Geographical Position and Geological Conditions}

Ganluo is located in the Dadu River basin, belonging to the Yangtze River, which has a rapid, large flow and high drop. In addition, its valleys are narrow and steep [23]. The Niri River is a tributary of the middle reaches of the Dadu River. Its riverbed is deep, and the average reduction ratio of riverbed slope is 11 parts per thousand in Ganluo County [24]. Along the Niri River, there are many large alluvial cones and diluvial fans, gradually widening to the south of the river, a floodplain, and intermittently distributed terraces (see Figure 6a). The valleys on both sides of the Niri River are steep, with slopes of $40^{\circ}$ to $70^{\circ}$ (see Figure 6b). The gradient of the slope has a great influence on the susceptibility to landslides. It is widely known that slope steepness is highly related to susceptibility to rapid landslides. When the dip angle of rock strata is greater than $40^{\circ}$, the bedding layer commonly controls the slope surface, and it is difficult to form landslides. However, when the lithology of the lower part of the slope body is weak or broken by tectonic action, the upper part of the slope body may form landslides with the upper bedding and lower cutting layers and the action of the bedding pushing force on the upper rock mass [25]. In addition to the above rock properties, the possibility of landslides and debris flow in the canyons on both sides of the riverbank is greatly increased due to the low vegetation coverage. 

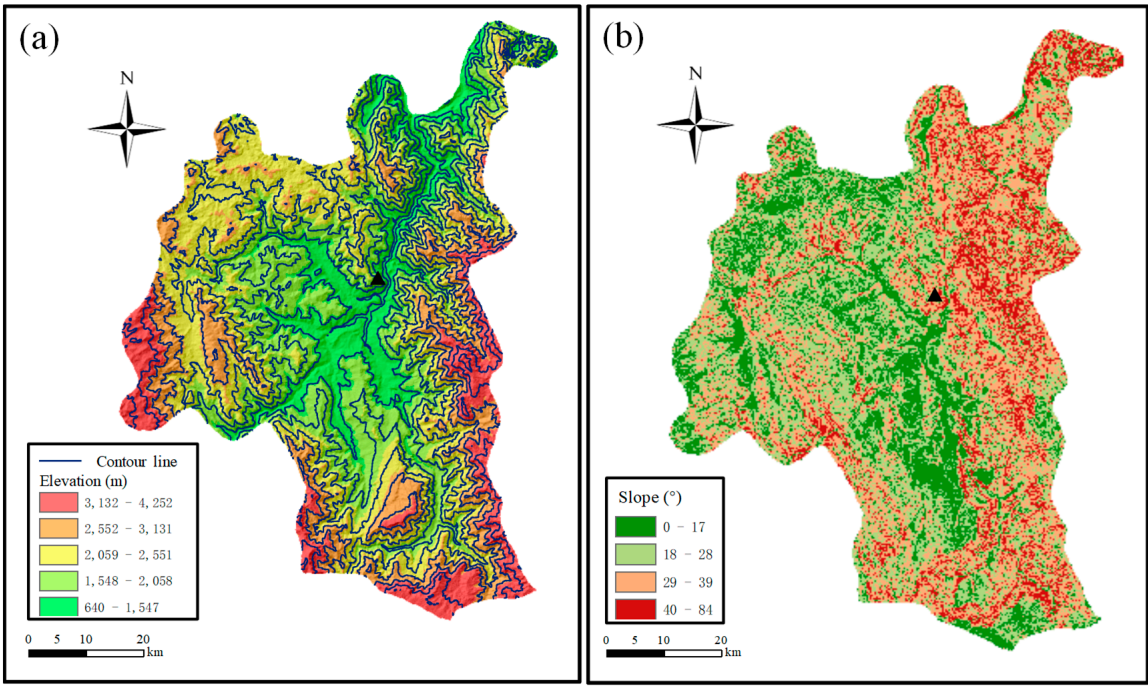

Figure 6. (a) Topographic mapping of Ganluo (black triangle: landslide site); (b) GIS slope figure (black triangle: landslide site).

\subsubsection{Seismic Fracture Zone}

Sichuan is an earthquake-prone area, and there have been many strong earthquakes around the site historically. Especially in the western region of the site, the Wenchuan earthquake Ms 8.0 in 2008 and the Lushan earthquake Ms 7.0 in 2013 both occurred near the site [26,27]. The Sichuan-Yunnan Plateau is a transition zone between the Qinghai-Tibetan Plateau and Sichuan Basin (see Figure 7). Under the pressure of the northward movement of the Indian Plate, it has become one of the most seismically active regions in the world [28]. These earthquakes may reduce the strength of the soil-rocks at the site [27] so that even the latest earthquake (on 29 July 2019) recorded near the site was only 3.3 magnitude in July to August in 2019 and which was $200 \mathrm{~km}$ away from the site. The earthquake was also a significant cause of the slide [29-32].

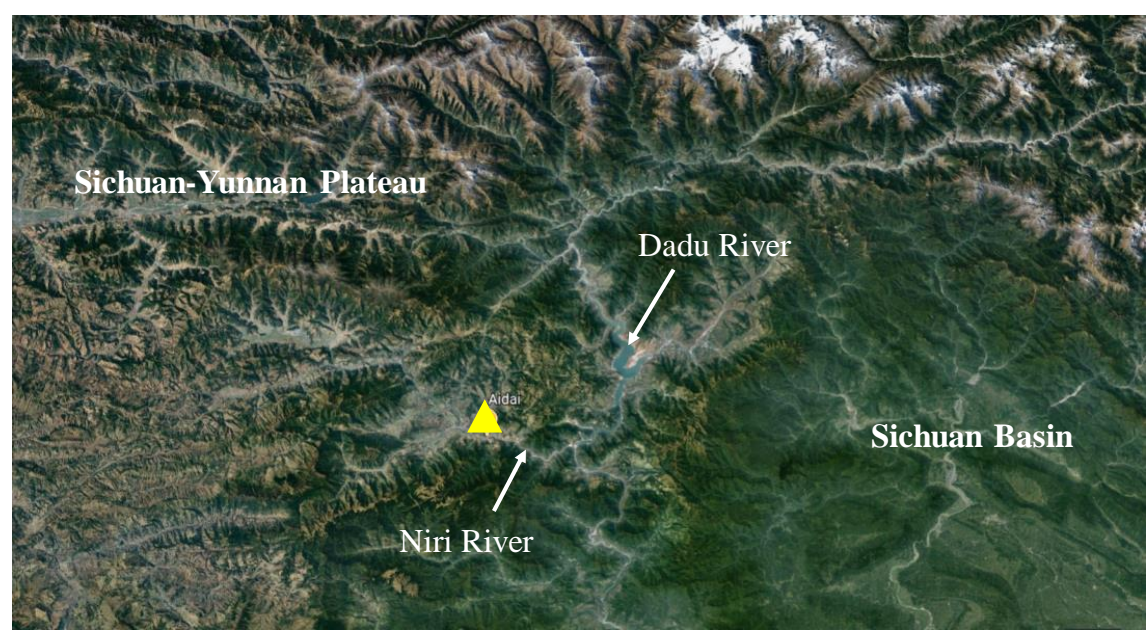

Figure 7. Topographic mapping of Ganluo County (yellow triangle) from Google Earth (yellow triangle shows the location of Ganluo).

\subsection{External Factors: Rainfall, Track Vibration and Flood Erosion}

\subsubsection{Rainfall}

Ganluo is located in a mountainous terrain in which the average annual rainfall is $880 \mathrm{~mm}$ [33]. The average rainfall in June, July and August were 202.7, 214.5 and $210.7 \mathrm{~mm}$, respectively 
(see Figure 8a). Rainwater was considered as the direct trigger in this landslide. From 26 July to 14 August 2019, 20 days of rainfall were recorded and the maximum rainfall was $136.91 \mathrm{~mm}$ on 3 August (see Figure 8b) which caused the mudslide on 4 August. It occurred approximately $70 \mathrm{~m}$ from where landslide A occurred. Figure 2 shows the seriously damaged vegetation on the surface of the mountains and the soil erosion. The continuous heavy rainfall caused serious soil loss, and the soil around the landslide location became extremely unstable. In addition, prior to the landslide (14 August), the rainfall was 24.13 and $8.13 \mathrm{~mm}$ on 13 and 14 August 2019, respectively (see Figure 8b). Abundant precipitation increases pore water pressure in the soils, leading to the decrease of their shear strength. The poor shear strength caused the collapse of the rock mass.

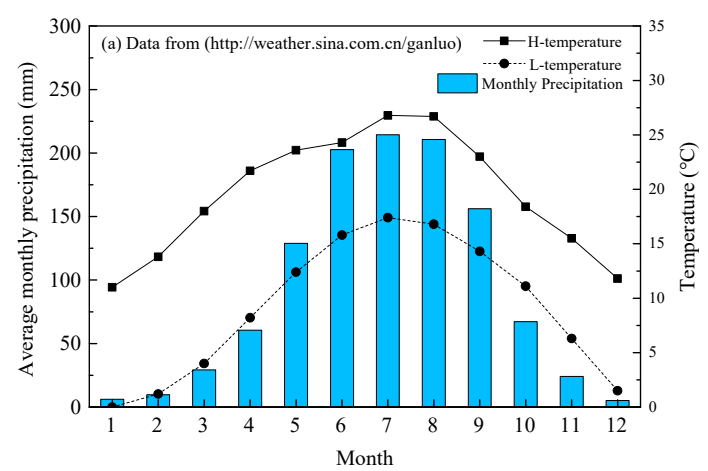

(a)

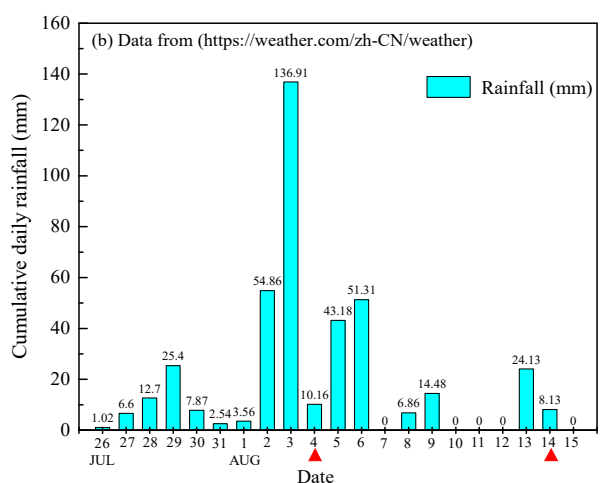

(b)

Figure 8. (a) Average monthly rainfall, the highest temperature ( $\mathrm{H}$ temperature), and the lowest temperature (L temperature) in Ganluo; (b) daily rainfall in Ganluo prior to landslide A (red triangles show the date of the landslides).

\subsubsection{Flood Erosion}

The induced effect of flowing water was mainly reflected in the slope instability caused by the erosion of the foot of the slope by the flowing water. This was an important inducing factor for several landslides along the Niri River. During the period from 25 July to 15 August 2019, because of the continuous heavy rainfall and the channel dam caused by the landslide that happened on 30 July 2019 (see Figure 9), the Niri River level rose sharply and significantly weakened the stability of the foot of the slope.

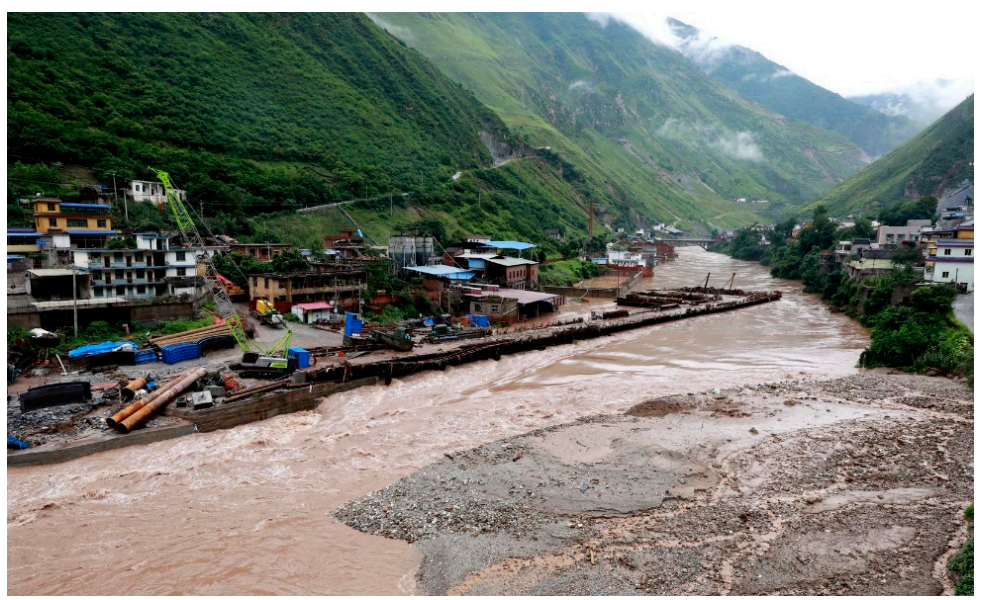

Figure 9. Flood and channel dam caused by the landslide at Aidai village on 30 July (picture source from [34]). 


\subsubsection{Human Activity}

The Chengdu-Kunming railway is the only railway connecting the southwest of China with the rest of the country. Considering the safety of the railway passengers in the rainy season and the demand for railway transportation for the economic development of this region, the EMD rushed to repair the railway line after the mudslide occurred on 4 August. After the railway line was repaired on 10 August, the railway authorities arranged this trial run of trains loaded with goods. At 12:44 on 14 August, shortly after a train passed the site at 12:40, the landslide occurred.

\subsection{Recommendations}

The Chengdu-Kunming railway is the only railway connected to the southwest region. It is essential for the economic development of this region. The railroad navigates many steep, geologically complex valleys located in remote mountainous areas with no human presence to monitor geological conditions. Landslide risk analysis, pre-disaster early warning, and post-disaster reconstruction management are three significant points when encountering a natural disaster. Therefore, the following recommendations are given to reduce human casualties and property loss.

1. Risk assessment should be conducted to reveal the risk level along the Chengdu-Kunming railway. There are many quantitative or statistical risk assessment methods able to predict landslide susceptibility, e.g., logistic regression (LR) [35], analytical hierarchy process (AHP) [36-41], and frequency ratio (FR). The landslide susceptibility can also be mapped using geographic information system (GIS) technology [36-44]. Based on a comparative study, Yalcin [45] concluded that the AHP method yielded a more realistic scenario regarding the actual distribution of landslide susceptibility. The application of these models can give guidance for monitoring the occurrence of a landslide.

2. Therefore, the application of remote sensing (RS) and GIS for landslide disaster management is necessary [15]. For instance, two consecutive landslides within a month starting on 11 October 2018 and twice blocked the Jinsha River which is the upper reaches of the Yangtze River at the junction of Sichuan Province and Tibet in China [46]. However, with the deployment of a real-time landslide early warning system, local authorities took immediate action to quickly and safely construct spillways to drain the dammed lake. It avoided the most serious cases, where loss of life and property is at least one order of magnitude lower than that observed without rapid intervention. Because the western region of Sichuan is the transition zone of the Sichuan Basin and Yun-Gui Plateau and the geological characteristics of these two regions are similar, the railway and its related departments can follow this model for further research and development of monitoring. The government may be able to obtain all the data from the time-lapse to the end of a landslide by monitoring areas where landslides occur on a long-term basis such as the example above. In addition, drones can also periodically measure the topography of the landslide's starting area, combined with GIS technology to analyse the time variation of the storage space distribution in the landslide's starting area $[36,38,47]$.

3. In Ganluo County, Sichuan Province, the summer rainfall is rich, and the groundwater is abundant [31]. Most landslides are triggered by rainfall, with the influence of the monsoon climate and environmental changes. The hydro-meteorological data also show that two series of early precipitation for 10 days may produce excess pore water pressure and high saturation in landslide and debris flow areas [48]. Therefore, the data using the rainfall assimilation method provides a new method for merging multisource data with models, which may be used to predict the displacement of landslides [49]. In addition, the landslide simultaneous state and parameter estimation strategy were able to make use of time-series displacements and hydrological information for the joint estimation of landslide displacement and model parameters. It was able to improve the performance considerably. The establishment of a groundwater flow model may be effective for better planning and location of landslide stability enhancement 
measures [50]. In addition to the methods mentioned above, relatively low-cost countermeasure could be employed to define rainfall thresholds that have been used as a base for an EWS in Emilia Romagna (Italy). Experiences show that only a few data are needed if a long-term research project is established, but the performance can improve greatly with time [51].

4. The deaths and missing persons at the landslide site were station staff and workers who were clearing the railway drains. Therefore, in such a remote area, if the geological survey and landslide warning after the landslide occur, similar casualties could be avoided. In particular, after the first mudslide (19 July) and landslide (4 August), measures such as reinforcement, blasting, or removal of the surrounding loose soil should be taken quickly.

\section{Concluding Remarks}

This article reports on the landslide that occurred on 14 August 2019 in Sichuan, China. After preliminary investigation and analysis, the following conclusions are drawn:

1. A moderate size landslide event, with about $48000 \mathrm{~m}^{3}$ of earth and rocks, occurred at Ganluo, resulting in 12 fatalities and five people reported as missing, destroying a section of the railway of approximately $70 \mathrm{~m}$ and causing this section of the train service to be suspended for 15 days.

2. The reason that caused the landslides were due to the combined effects of frequent former earthquakes, steep topography, large amounts of rainfall water, deep-seated sliding interface, dynamic train running load, and the effects of the previous two geological disasters, etc. These effects led to severe casualties and environmental impacts. For prevention and mitigation of these slide hazards, risk assessment concerning landslides should be conducted first to reveal the risk level along the Chengdu-Kunming railway line. Based on the risk assessment results, early warning systems should be provided through cost-effective precipitation and groundwater sensing technologies as well as the establishment of GIS databases to continuously monitor geologically risk-prone areas.

3. After the landslide disaster, continuous monitoring of the surrounding soil in a timely manner should be conducted to deploy and evacuate relevant rescue workers. Disaster prevention education for villagers living in vulnerable areas is also important. This will reduce casualties in similar incidents in the future.

Author Contributions: This paper represents the result of collaborative teamwork. S.-L.S. developed the concept; Q.Z. drafted the manuscript; A.-N.Z. and H.C. provided constructive suggestions and revised the manuscript. The four authors contributed equally to this work.

Funding: This research was funded by the Research Funding of Shantou University for New Faculty (Grant No. NTF19024-2019).

Acknowledgments: The authors would like to express sincere thanks to the anonymous reviewers and editors. Their constructive comments help the authors to improve the quality of the manuscript.

Conflicts of Interest: The authors declare no conflict of interest.

\section{References}

1. Petley, D. Global patterns of loss of life from landslides. Geology 2012, 40, 927-930. [CrossRef]

2. Battistini, A.; Segoni, S.; Manzo, G.; Catani, F.; Casagli, N. Web data mining for automatic inventory of geohazards at national scale. Appl. Geogr. 2013, 43, 147-158. [CrossRef]

3. Dowling, C.A.; Santi, P.M. Debris flows and their toll on human life: A global analysis of debris-flow fatalities from 1950 to 2011. Nat. Hazards 2014, 71, 203-227. [CrossRef]

4. Ministry of Emergency Management, PRC (MEMPRC). Basic Situation of Natural Hazards of China in 2018, MEMPRC. Available online: http://www.mem.gov.cn/xw/zhsgxx/201901/t20190108_242580.shtml (accessed on 9 January 2019). (In Chinese)

5. Wang, G.X. Key technique in landslide control and its handling measures. Chin. J. Rock Mech. Eng. 2005, 24, 3818. (In Chinese) [CrossRef] 
6. Dai, F.C.; Lee, C.F.; Ngai, Y.Y. Landslide risk assessment and management: An overview. Eng. Geol. 2002, 64, 65-87. [CrossRef]

7. Hu, X.; Hu, K.; Tang, J.; You, Y.; Wu, C. Assessment of debris-flow potential dangers in the Jiuzhaigou Valley following the August 8, 2017, Jiuzhaigou earthquake, western China. Eng. Geol. 2019, 256, 57-66. [CrossRef]

8. Wang, L.; Yin, Y.; Huang, B.; Zhang, Z.; Wei, Y. Formation and characteristics of Guang'an Village landslide in Wuxi, Chongqing, China. Landslides 2019, 16, 127-138. [CrossRef]

9. Meng, W.; Xu, Y.; Cheng, W.C.; Arulrajah, A. Landslide event on 24 June in Sichuan Province, China: Preliminary investigation and analysis. Geosciences 2018, 8, 39. [CrossRef]

10. Piciullo, L.; Calvello, M.; Cepeda, J.M. Territorial early warning systems for rainfall-induced landslides. Earth Sci. Rev. 2018, 179, 228-247. [CrossRef]

11. Chae, B.G.; Park, H.J.; Catani, F.; Simoni, A.; Berti, M. Landslide prediction, monitoring and early warning: A concise review of state-of-the-art. Geosci. J. 2017, 21, 1033-1070. [CrossRef]

12. Baum, R.L.; Godt, J.W. Erratum to: Early warning of rainfall-induced shallow landslides and debris flows in the USA. Landslides 2010, 7, 387. [CrossRef]

13. Graziella, D.; Ingeborg, K.; Monica, S.; Nils-Kristian, O.; Ragnar, E.; Erik, J.; Hervé, C. Landslide early warning system and web tools for real-time scenarios and for distribution of warning messages in Norway. In Engineering Geology for Society and Territory; Springer: Cham, Switzerland, 2015; Volume 2, pp. 625-629. [CrossRef]

14. Kim, D.; Lee, C.; Woo, C.; Seo, J.; Kang, M.; Kwon, H. The pilot construction of a sensor-based landslide early warning system for mitigating human damages, Republic of Korea. In Proceedings of the Workshop on World Landslide Forum, Ljubljana, Slovenia, 29 May-2 June 2017; Springer: Cham, Switzerland, 2017; pp. 139-145. [CrossRef]

15. Ayele, S.; Raghuvanshi, T.K.; Kala, P.M. Application of Remote Sensing and GIS for Landslide Disaster Management: A Case from Abay Gorge, Gohatsion-Dejen Section, Ethiopia. In Landscape Ecology and Water Management; Springer: Tokyo, Japan, 2014; pp. 15-32. [CrossRef]

16. Southern Metropolis Daily. Straight into the Cheng-Kun Railway Mountain Collapse Moment: No Warning Suddenly Loud Bang, Sand Blocks Hit Four or Five People Flying. Available online: http://ishare.ifeng.com/ c/s/7pFZ1eWNWhb (accessed on 19 August 2019). (In Chinese).

17. Xinhua News Agency New Media. Satellite Images Tell You Why the Chengkun Railway has been Disrupted Several Times Recently. Available online: https://baijiahao.baidu.com/s?id=1642026512324615782\&wfr= spider\&for=pc (accessed on 16 August 2019). (In Chinese).

18. People's Network Sichuan Channel. Emergency Rescue of Armed Police Officers and Soldiers for Landslides Caused by Heavy Rainfall in Ganluo, Sichuan. Available online: http://k.sina.com.cn/article_2086029453_ p7c56488d027015xxj.html?from=news\&subch=photo) (accessed on 15 August 2019). (In Chinese).

19. Sina News. The Instant of Life and Death on Chengdu-Kunming line: Stone Ran after Him and was Buried One or Two Seconds Later. Available online: https://news.sina.com.cn/c/2019-08-19/doc-ihytcitn0163880.shtml (accessed on 19 August 2019). (In Chinese).

20. China High-Resolution Observation. Sichuan Center of High Score Observation Fully Supports Disaster Emergency Rescue Work in Ganluo County and Wenchuan County. Available online: https://mp.weixin.qq. com/s/Gken4y6yr5WutJFWpmDUMA (accessed on 22 August 2019). (In Chinese).

21. Beijing-Tianjin Network. Chengdu-Kunming Railway Rescue Progress: Four Suspected Bodies Are Being Recovered and the Identities Are Being Verified. Available online: https://baijiahao.baidu.com/s?id= $1642166585279450425 \& w f r=s p i d e r \& f o r=p c$ (accessed on 18 August 2019). (In Chinese).

22. Southern Metropolitan Daily. Chengdu-Kunming Railway Mountain Collapse Site Found 4 Suspected Missing Bodies! Identification Is Being Verified. Available online: http://ishare.ifeng.com/c/s/7pDcVeekE0G (accessed on 17 August 2019). (In Chinese).

23. Sun, X.F.; Bai, Z.Y.; Li, D.L. Control Action of Geological Structure on Development Law of Debris Flow at Ebian-Dechang Section of Chengdu-Kunming Railway. Subgrade Eng. 2012, 4, 57. (In Chinese) [CrossRef]

24. Liu, Y.L.; Wu, J.; Tang, Y.; Yang, G.; Zhu, L. An investigation of heavy-metal concentration in dominant plant species in a zinc-lead mining area in Ganluo County of Sichuan Province. Acta Ecol. Sin. 2009, 29, 2020-2026. (In Chinese) [CrossRef]

25. Liu, Y.S.; He, Z.-W.; Wu, D.-C.; Xiao, Y.-F.; Zhou, R.-B. Geomorphic Features of the Jinchuan-Badi Sector of the Dadu River Valley. Acta Geol. Sichuan 2007, 27, 162-165. (In Chinese) [CrossRef] 
26. Tang, R.; Fan, X.; Scaringi, G.; Xu, Q.; van Westen, C.J.; Ren, J.; Havenith, H.B. Distinctive controls on the distribution of river-damming and non-damming landslides induced by the 2008 Wenchuan earthquake. Bull. Eng. Geol. Environ. 2019, 78, 4075-4093. [CrossRef]

27. Wang, G.; Zhang, M.; Peng, J.; Zhu, H. Landslides triggered by the Ms 7.0 earthquake of 20 April 2013 in Lushan, SW China. In Landslide Science for a Safer Geoenvironment; Springer: Cham, Switzerland, 2014; pp. 141-148. [CrossRef]

28. Lou, H.; Wang, C.Y. Wavelet analysis and interpretation of gravity data in Sichuan-Yunnan region, China. Acta Seismol. Sin. 2005, 18, 552-561. [CrossRef]

29. Fan, X.; Xu, Q.; Scaringi, G. Brief communication: Post-seismic landslides, the tough lesson of a catastrophe. Nat. Hazards Earth System Sci. 2018, 18, 397-403. [CrossRef]

30. Fan, X.; Scaringi, G.; Korup, O.; West, J.A.; Westen, C.J.V.; Tanyas, H.; Hovius, N.; Hales, T.C.; Jibson, R.W.; Allstadt, K.E.; et al. Earthquake-Induced Chains of Geologic Hazards: Patterns, Mechanisms, and Impacts. Rev. Geophys. 2019, 57, 421-503. [CrossRef]

31. Fan, X.; Xu, Q.; Scaringi, G.; Dai, L.X.; Li, W.L.; Dong, X.J.; Zhu, X.; Pei, X.J.; Dai, K.R.; Havenith, H.B. Failure mechanism and kinematics of the deadly June 24th 2017 Xinmo landslide, Maoxian, Sichuan, China. Landslides 2017, 14, 2129-2146. [CrossRef]

32. Fan, X.; Xu, Q.; Scaringi, G.; Zheng, G.; Huang, R.; Dai, L.; Ju, Y. The "long" runout rock avalanche in Pusa, China, on August 28, 2017: A preliminary report. Landslides 2019, 16, 139-154. [CrossRef]

33. China Weather News. Ganluo County Introduction. Available online: www.weather.com.cn/cityintro/ 101271616.shtml (accessed on 25 November 2019). (In Chinese).

34. Sina News. Rain Storms Hitting Liangshan Ganluo County, Affecting 15,000 People, Leaving Seven Missing. Available online: https://news.sina.com.cn/o/2019-07-30/doc-ihytcerm7386644.shtml (accessed on 30 July 2019). (In Chinese).

35. Shahabi, H.; Khezri, S.; Ahmad, B.B.; Hashim, M. Landslide susceptibility mapping at central Zabbasin, Iran: A comparison between analytical hierarchy process, frequency ratio and logistic regression models. Catena 2014, 115, 55-70. [CrossRef]

36. Lyu, H.M.; Shen, S.L.; Zhou, A.N.; Yang, J. Risk assessment of mega-city infrastructures related to land subsidence using improved trapezoidal FAHP. Sci. Total Environ. 2019. [CrossRef]

37. Lyu, H.M.; Wang, G.F.; Cheng, W.C.; Shen, S.L. Tornado hazards on June 23rd in Jiangsu Province, China: Preliminary investigation and analysis. Nat. Hazards 2017, 85, 597-604. [CrossRef]

38. Lyu, H.M.; Shen, S.L.; Yang, J.; Yin, Z.Y. Inundation analysis of metro systems with the storm water management model incorporated into a geographical information system: A case study in Shanghai. Hydrol. Earth Syst. Sci. 2019, 23, 4293-4307. [CrossRef]

39. Lyu, H.M.; Sun, W.J.; Shen, S.L.; Zhou, A.N. Risk assessment using a new consulting process in fuzzy AHP. J. Constr. Eng. Manag. 2019. [CrossRef]

40. Lyu, H.M.; Shen, S.L.; Zhou, A.N.; Zhou, W.H. Flood risk assessment of metro systems in a subsiding environment using the interval FAHP-FCA approach. Sustain. Cities Soc. 2019, 50, 101682. [CrossRef]

41. Lyu, H.M.; Shen, S.L.; Zhou, A.N.; Yang, J. Perspectives for flood risk assessment and management for mega-city metro system. Tunn. Undergr. Space Technol. 2019, 84, 31-44. [CrossRef]

42. Peng, J.; Peng, F.L. A GIS-Based evaluation method of underground space resource for urban spatial planning: Part 1 Methodology. Tunn. Undergr. Space Technol. 2018, 74, 82-95. [CrossRef]

43. Qiao, Y.K.; Peng, F.L.; Wang, Y. Monetary valuation of urban underground space: A critical issue for the decision-making of urban underground space development. Land Use Policy 2017, 69, 12-24. [CrossRef]

44. Qiao, Y.K.; Peng, F.L.; Sabri, S.; Rajabifard, A. Low carbon effects of urban underground space. Sustain. Cities Soc. 2019, 45, 451-459. [CrossRef]

45. Yalcin, A. GIS-based landslide susceptibility mapping using analytical hierarchy process and bivariate statistics in Ardesen (Turkey): Comparisons of results and confirmations. Catena 2008, 72, 1-12. [CrossRef]

46. Fan, X.; Xu, Q.; Alonso-Rodriguez, A.; Subramanian, S.S.; Li, W.; Zheng, G.; Dong, X.J.; Huang, R.Q. Successive landsliding and damming of the Jinsha River in eastern Tibet, China: Prime investigation, early warning, and emergency response. Landslides 2019, 16, 1003-1020. [CrossRef]

47. Imaizumi, F.; Masui, T.; Yokota, Y.; Tsunetaka, H.; Hayakawa, Y.S.; Hotta, N. Initiation and runout characteristics of debris flow surges in Ohya landslide scar, Japan. Geomorphology 2019, 339, 58-69. [CrossRef] 
48. Setiawan, H.; Wilopo, W.; Wiyoso, T.; Fathani, T.F.; Karnawati, D. Investigation and numerical simulation of the 22 February 2018 landslide-triggered long-traveling debris flow at Pasir Panjang Village, Brebes Regency of Central Java, Indonesia. Landslides 2019, 1-14. [CrossRef]

49. Wang, J.; Nie, G.; Gao, S.; Xue, C. Simultaneous state-parameter estimation of rainfall-induced landslide displacement using data assimilation. Nat. Hazards Earth Syst. Sci. 2019, 19. [CrossRef]

50. Shrestha, H.K.; Yatabe, R.; Bhandary, N.P. Groundwater flow modeling for effective implementation of landslide stability enhancement measures. Landslides 2008, 5, 281-290. [CrossRef]

51. Segoni, S.; Rosi, A.; Fanti, R.; Gallucci, A.; Monni, A.; Casagli, N. A Regional-Scale Landslide Warning System Based on 20 Years of Operational Experience. Water 2018, 10, 1297. [CrossRef]

(C) 2019 by the authors. Licensee MDPI, Basel, Switzerland. This article is an open access article distributed under the terms and conditions of the Creative Commons Attribution (CC BY) license (http://creativecommons.org/licenses/by/4.0/). 